\title{
Yield of 'Pingo de Ouro' Cowpea Bean Under Different Sowing Densities and Goat Manure Doses in the Region of Mossoró, Brazil
}

\author{
Rogério Alexandrino da Silva ${ }^{1}$, Paulo César Ferreira Linhares ${ }^{1}$, Anielson dos Santos Souza ${ }^{2}$, \\ Maria Francisca Soares Pereira ${ }^{1}$, Janilson Pinheiro de Assis ${ }^{1}$, Roberto Pequeno de Sousa ${ }^{1}$, Ariana Morais Neves ${ }^{1}$, \\ Lunara de Sousa Alves ${ }^{3} \&$ Rita Ianáskara Gomes da Silva ${ }^{1}$ \\ ${ }^{1}$ Jitirana Research Group, Department of Agronomic and Forestry Sciences, Federal Rural Semi-Arid University, \\ Mossoró, RN, Brazil \\ ${ }^{2}$ Center of Food Science and Technology, Federal University of Campina Grande, Pombal, PB, Brazil \\ ${ }^{3}$ Federal University of Paraiba, Campus Areia, Areia, PB, Brazil \\ Correspondence: Rogério Alexandrino da Silva, Jitirana Research Group, Department of Agronomic and \\ Forestry Sciences, Federal Rural Semi-Arid University, Mossoró, RN, Brazil. E-mail: agrogerio@hotmail.com
}

Received: August 18, 2018

doi:10.5539/jas.v10n12p329
Accepted: September 28, 2018

Online Published: November 15, 2018

URL: https://doi.org/10.5539/jas.v10n12p329

\begin{abstract}
Using goat manure may substantially increase cowpea bean productivity. This study evaluated the yield of 'pingo de ouro' cowpea bean under different sowing densities and goat doses in the region of Mossoró, Brazil. The experiment was conducted from October to December 2016 at the Experimental Farm Rafael Fernandes, Mossoró-RN, Brazil. Treatments arranged in two-way factorial with four goat manure doses $(0.0,0.5,1$ and $2 \mathrm{~kg}$ $\left.\mathrm{m}^{-1}\right)$, and two sowing densities of bean $\left(75,000\right.$ and 37,500 plants ha $\left.{ }^{-1}\right)$, with three replicates. The experiment was performed in complete randomized blocks design. We evaluated the number and length of pods per plant, number of seed per pod, weight of 100 dry grains and dry grain yield. Higher grain yield occurred using $2.0 \mathrm{~kg} \mathrm{~m}^{-1}$ of goat

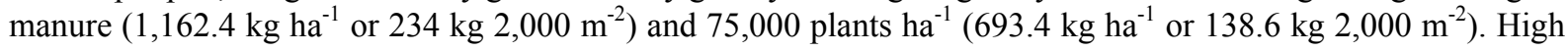
sowing density in combination with goat manure is an affective.
\end{abstract}

Keywords: organic fertilizer, sustainability, Vigna unguiculata

\section{Introduction}

The cowpea (Vigna unguiculata (L.) Walp) is one of the main food sources of tropical regions because it contains substantial lipids, sugars, calcium, iron, potassium, phosphorus and several essential amino acids (Cardoso \& Ribeiro, 2006).

In the state of Rio Grande do Norte, Brazil, the cultivation of cowpea generates employment and income. The cultivation takes place in small areas, where the farmers cultive varieties adapted to the climatic conditions of the region. Brazil stands out among the bean-producing countries, occupying the third position, with an average production of $1.083 \mathrm{~kg} \mathrm{ha}^{-1}$ (IBGE, 2017).

The rusticity, precocity and the wide adaptability allow the cultivation of cowpea in aggressive environments, an essential characteristic for the northeastern region of Brazil (Souza et al., 2013). In this region, climate is semi-arid, and string beans stand out as a significant crop that used as major source of proteins and carbohydrates, in the form of dry and green grains (Lima, 2014). The Brazilian states with the highest per capita consumption of beans are Ceará and Piauí, predominantly using cowpea (Wander, 2007).

Despite the low productivity of grains in the Northeast, the cultivation of cowpea beans can be an alternative of consumption and income through the cultivation of the 'Pingo de Ouro' variety. Many farmers in the State of Rio Grande do Norte consider the 'Pingo de Ouro' variety more productive than other local varieties, such as 'Centa de Vaca' and 'Canapu'. The use of local varieties contributes greatly to the reduction of production costs (Carpentieri-Pípolo et al., 2010). Goat manure is a source of organic matter that is easily available and can be used for fertilization. A positive effect of goat manure application was found in sunflower (Pereira et al., 2014), maize (Oliveira et al., 2016) and lettuce (Figueiredo et al., 2012). 
In addition to fertilization, the definition of ideal seeding density contributes to increasing the productivity of cowpea. Therefore, proper management of the culture, balancing the production factors, is fundamental to achieve optimum productivity (Cardoso Melo \& Andrade Junior, 1997). However, studies testing different seeding densities for beans of the local varieties are still scarce.

Thus, due to the importance of cowpea in the High West region of Rio Grande do Norte, this study aimed to evaluate the impact of goat manure and sowing densities on yield of cowpea Pingo of Ouro type.

\section{Materials and Methods}

The research was developed October to December 2016 in an area in the community of Alagoinha, belonging to the Federal Rural University of the Semi-arid from October to December 2016, rural area of Mossoró-RN, Brazil $\left(5^{\circ} 03^{\prime} 37^{\prime \prime} \mathrm{S}, 37^{\circ} 23^{\prime} 50^{\prime \prime} \mathrm{W}\right)$. The climate is BSwh', dry and very hot according to the Köppen classification, with a dry season from June to January, and a rainy season from February to May (Carmo Filho \& Oliveira, 1989). Average annual rainfall of $673.9 \mathrm{~mm}$ and average relative humidity of $68.9 \%$. The soil was classified as Argisolic Yellow Latosol (Embrapa, 2006).

Before set up of the study, samples of soil were collected from the 0-20 cm layer. These soil samples, were air dried and sieved in a $2 \mathrm{~mm}$ mesh, an then analyzed at the Soil Chemistry and Fertility Laboratory of Universidade Federal Rural do Semi-Árido (UFERSA). The results from the laboratory testing at UFERSA were the following: $\mathrm{pH}\left(\right.$ water 1:2.5) $=6.64$; exchangeable cations $\mathrm{Ca}=1.30 \mathrm{cmol}_{\mathrm{c}} \mathrm{dm}^{-3} ; \mathrm{Mg}=0.60 \mathrm{cmol}_{\mathrm{c}} \mathrm{dm}^{-3} ; \mathrm{K}=34.5 \mathrm{mg} \mathrm{dm}^{-3} ; \mathrm{Na}$ $=10.7 \mathrm{mg} \mathrm{dm}^{-3} ; \mathrm{P}($ Mehlich $)=34.5 \mathrm{mg} \mathrm{dm}{ }^{-3} ; \mathrm{N}=0.77 \mathrm{~g} / \mathrm{kg}$ and $\mathrm{M} . \mathrm{O}=2.48 \mathrm{~g} \mathrm{~kg}^{-1}$.

The experiment was conducted in complete randomized blocks, in a $4 \times 2$ factorial design three replications. Treatments included four doses of goat manure $\left(0.0 ; 0.5 ; 1.0\right.$ and $\left.2.0 \mathrm{~kg} \mathrm{~m}^{-1}\right)$, for the plant density of 75,000 and 35,000 plants ha $^{-1}$ a the spacing of $0.4 \times 1.0 \mathrm{~m}, 0.8 \times 1.0 \mathrm{~m}$ were used respectively. The densities were choose based on the densities used by cowpea producers in the municipality of Frutuoso Gomes, RN.

Farmers from Frutuoso Gomes-RN commonly use the local variety 'Pingo de Ouro', which was used at this work. Each experimental unity consisted of 6 meters with 45 and 21 plants at the spacing of 0.4 and $0.8 \mathrm{~m}$, respectively. The soil was prepared by plowing and grading. The experiment was irrigated by a drip system, with one hose per block, and emitters spaced at $0.40 \mathrm{~m}$, with flow rate of $1.5 \mathrm{~L} \mathrm{~h}^{-1}$.

The goat manure used was sourced from of the UFERSA, which are raised in an intensive system, fed with corn-based concentrate, soy bean and wheat bran, and having as bulk Canarian grass (Echinocloa polystochya), the chemical concentration manure was included: $\mathrm{pH}$ (water 1:2.5) $=8.06$; and the total contents of $16.5 \mathrm{~g} \mathrm{~kg}^{-1}$ of $\mathrm{N} ; 6.6 \mathrm{~g} \mathrm{~kg}^{-1}$ of P; $19.0 \mathrm{~g} \mathrm{~kg}^{-1}$ of K $\mathrm{K}^{+} ; 0.849 \mathrm{~g} \mathrm{~kg}^{-1}$ of Na

Seeds used came from the farmers of Frutuoso Gomes-RN. Sowing was carried out on October 6, 2016, by placing five seeds per hole. Fifteen days after sowing two plants were removed, and remaining three plants per hole kept throughout the experiment.

Irrigation was performed twice a day for 60 minutes. Weeds were removed at every 15 days. For the control and prevention of pests, such as caterpillars, leafminer, and aphids, the NeenMax Insecticide, (Azadirachtin) was used, at the dose of $10 \mathrm{ml}_{\text {liter }}^{-1}$.

Harvest of the dry pods was made manually. At the Laboratório de Pós-Colheita de Hortaliças of the Departamento de Ciências Vegetais of UFERSA, we measured the number and length of pods per plant, number of seeds per pod, weight of 100 dry grains and yield of dry grains.

The average number of pods per plant: was obtained through the sum of all pods of the plot, except for the border, divided by the number of plants. The mean length of pods per plant: was evaluated in a random sample of 15 plants of each plot, measuring all pods of the plants using a graduated ruler in centimeters. The average number of seeds: determined from a sample of 20 randomly selected pods from the useful area of each plot, expressed as seed pod ${ }^{-1}$. The weight of 100 dry grains: was obtained using a digital scale with an accuracy of $1 \mathrm{~g}$. The dry grain yield: was determined from the weight of the dry grains of the area of each plot and expressed in $\mathrm{kg} \mathrm{ha}^{-1}$ and $\mathrm{kg} 2.000 \mathrm{~m}^{-2}$.

Analyses of variance (ANOVA) were used to verify the effects of the manure and density of seeds on the response variables of Pingo de Ouro variety. Regressions were made to analyze the relations of the response variables with the increase in manure doses, using the software ESTAT (Kronka \& Banzato, 1995).

\section{Results and Discussion}

We found a significant interaction $(\mathrm{p}<0.05)$ among manure doses and the sowing densities for the weight of 100 grains and mean length of pods per plant (Table 1). In the goat manure dose, there was a significant effect $(\mathrm{p}<$ 0.01 ) on the number of pods per plant, number of seeds per pod, weight of 100 dry grains and yield of grams of 
cowpea bean. For seeding density factor, there was a significant effect $(\mathrm{p}<0.01)$ for on number pods per plant and $(\mathrm{p}<0.05)$ for yield $2000 \mathrm{~m}^{-2}$ and yield in $\mathrm{kg} \mathrm{ha}^{-1}$ of dry grains (Table 1).

Table 1. Results of the Analyses of Variance (ANOVA) for the effects of goat manure and density of seeding on the number and length of pods per plant (NP, LP, respectively), the number of seeds per pod (NS), the weight of 100 dry grains $\left(\mathrm{W}_{100 \mathrm{~g}}\right.$ ), yield 2,000 $\mathrm{m}^{-2}$ (Yield 2,000 $\mathrm{m}^{-2}$ ) and yield in $\mathrm{kg} \mathrm{ha}^{-1}$ of dry grains (YDG) of cowpea bean

\begin{tabular}{llllllll}
\hline Causes of variation & DF & LP & NP & NS & $\mathrm{W}_{100 \mathrm{~g}}$ & YIELD 2,000 m ${ }^{-2}$ & YDG \\
\hline Goat manure (A) & 3 & $1.9^{\text {ns }}$ & $29.3^{* *}$ & $7.8^{* *}$ & $1.2^{\text {ns }}$ & $30.3^{* *}$ & $30.3^{* *}$ \\
Seeding density (B) & 1 & $0.5^{\text {ns }}$ & $13.9^{* *}$ & $1.7^{\text {ns }}$ & $2.2^{\text {ns }}$ & $7.7^{*}$ & $7.7^{*}$ \\
A $\times$ B & 3 & $3.4^{*}$ & $3.1^{\text {ns }}$ & $2.4^{\text {ns }}$ & $3.4^{*}$ & $2.4^{\text {ns }}$ & $2.3^{\text {ns }}$ \\
Blocks & 2 & $2.4^{\text {ns }}$ & $1.5^{\text {ns }}$ & $0.2^{\text {ns }}$ & $1.4^{\text {ns }}$ & $1.5^{\text {ns }}$ & $1.5^{\text {ns }}$ \\
Residual & 14 & - & - & - & - & - & - \\
CV $(\%)$ & - & 8.1 & 34.6 & 13.9 & 5.1 & 33.9 & 33.9 \\
Average & - & 16.9 & 5.7 & 11.5 & 23.5 & 116.3 & 581.3 \\
\hline
\end{tabular}

Note. ${ }^{\mathrm{ns}}, *, * *$ not significant, significant at $5 \%$ and $1 \%$ probability of error by the $\mathrm{F}$ test of ANOVA, respectively.

$\mathrm{NP}$ and LP = Number and length of pods per plant, respectively; NS = Number of seeds per pod; $\mathrm{W} 100 \mathrm{~g}=$ Weight of 100 dry grains; YIELD 2,000 $\mathrm{m}^{-2}=$ yield $2,000 \mathrm{~m}^{-2}$ and $\mathrm{YDG}=$ Yield of dry grains.

Using goat manure in the organic cultivation of cowpea positively influenced the productive in the two planting densities studied. Therefore, seems a viable alternative by farmers to reach greater optimization in production.

The maximum length of 18.72 and $18.36 \mathrm{~cm}$ of pod per plant was found at the doses of 1.0 and $2.0 \mathrm{~kg} \mathrm{~m}^{-2}$, respectively (Figures 1a and 1b). There was no general difference among densities of sowing for the length of pods (16.7 and $16.6 \mathrm{~cm} \mathrm{pod}^{-1}$ for 75,000 and 37,500 plants ha ${ }^{-1}$, respectively). Lower values of 15.4 and 15.8 for cariri and cape varieties, respectively, were observed by Santos et al. (2009). Other studies also found small length of pods for cowpea beans (Torres et al., 2008; Torres Filho et al., 2013). Higher lengths are found for other varieties, 19.12 for 'Siempre Verde', 19.63 for 'Costela de Vaca' (Santos \& Lima, 2015), 21.6 for BRS Juruá (Cavalcante et al., 2013).
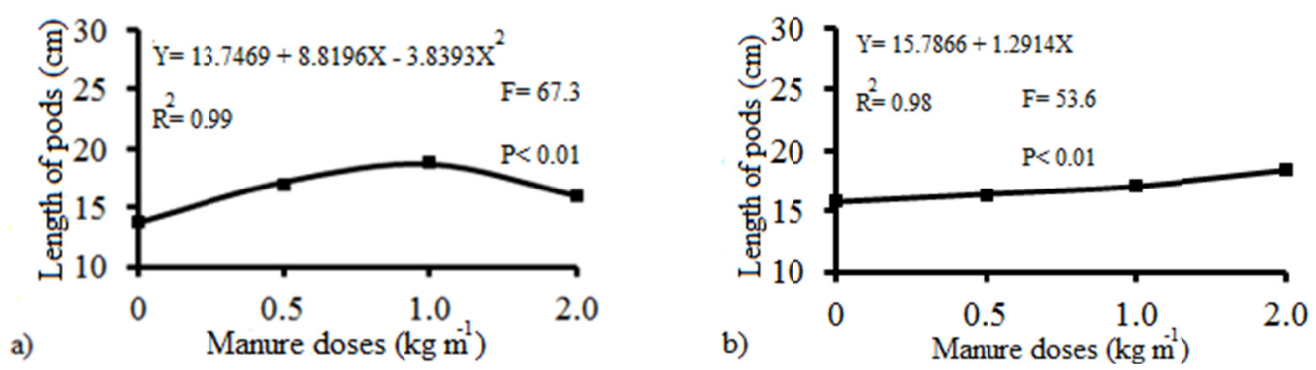

Figure 1. Mean length of pods per plant in function of the goat manure doses for seeding densities of 75,000 plants $\mathrm{ha}^{-1}$ (a) and 35,500 plants ha ${ }^{-1}$ (b) of cowpea bean

The higher number seeds per pods was found for $1.0 \mathrm{~kg} \mathrm{~m}^{-1}$ of goat manure dose, having 13.2 seeds per pod (Figure 2). There was no difference of the number of seeds between the seeds densities (11.1 and 11.9 seeds per pod for the treatments with 75,000 and 37,500 plants per ha, respectively).

Santos and Lima (2015) found 15.29 and 13.71 seeds per pod for the varieties Costela de Vaca and Sempre Verde, respectively. Torres Filho et al. (2013) measured values among 8.65 and 12.60, Sousa et al. (2013) found 10.75 to 14.85 for BRS Tumucumaque, and Santos reported 13 seeds per pod for BRS Xiquexique variety. 


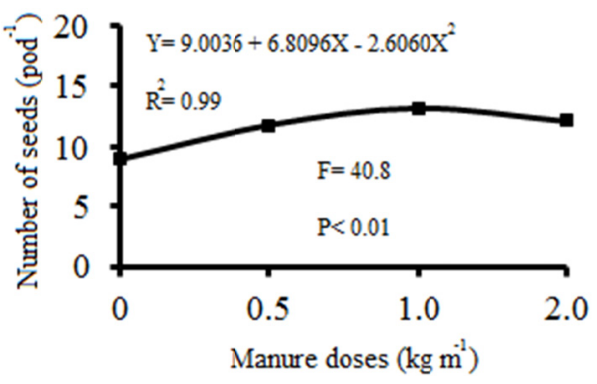

Figure 2. Average number of seeds per pod in function of the goat manure doses of cowpea bean

The number of pods increased with goat manure dose (Figure 3), resulting in an average increase of 10.3 pods between the lowest dose $\left(0 \mathrm{~kg} \mathrm{~m}^{-1}\right)$ and the highest dose $\left(2.0 \mathrm{~kg} \mathrm{~m}^{-1}\right)$. The treatments with 35,000 seeds ha ${ }^{-1}$ had a higher number of pods (7.1) than treatments with 75,000 plants ha ${ }^{-1}(4.2)$.

The addition of goat manure leads to vigorous plants with greater leaf area, probably promoting a more significant accumulation of photoassimilates, essential for the production of pods per plant. The density of seeds at the sowing affected the number of seeds per pod, showing an increase in competition by nutrients, water and space with the increase of seed density sown.

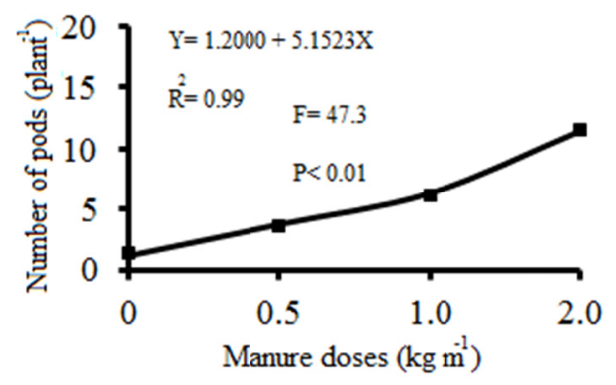

Figure 3. Mean number of pods per plant in function of the goat manure doses of cowpea bean

Freitas (2015) dry and green grains reported 18 and 23.1 pods plant $^{-1}$, values higher than we found. The results by Freitas et al. are probably are consequence of the lower seed densities $\left(20,000\right.$ plants $\left.^{-1} a^{-1}\right)$ and the chemical fertilizer used.

Matos Filho et al. (2009) also found higher values for local varieties. The high number of pods plant ${ }^{-1}$ show the great genetic potential of these bean varieties besides the desirable traits.

Unfolding the interaction of the goat manure doses within the densities $\left(75,000\right.$ and 37,500 plants $\left.\mathrm{ha}^{-1}\right)$ in the weight of 100 dry grains, whit mean values of weight of 100 dry grains of 25.07 and $26.3 \mathrm{~g}$ at the dose of $2.0 \mathrm{~kg} \mathrm{~m}^{-1}$, respectively for the densities 75,000 and 37,500 plants $\mathrm{ha}^{-1}$ (Figure $4 \mathrm{a}$ and $4 \mathrm{~b}$ ). Unfolding the interaction of the densities $\left(75,000\right.$ and 37,500 plants ha $\left.^{-1}\right)$ within of the goat manure doses, statistical difference only at the dose of $0 \mathrm{~kg} \mathrm{~m}^{-1}$, with mean values of 21.2 and $24.3 \mathrm{~g}$, respectively.
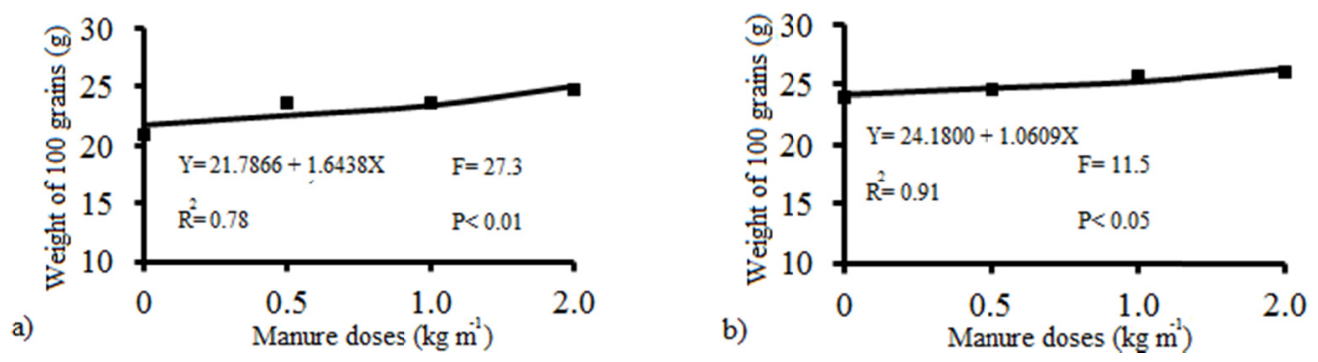

Figure 4. Mean weight of 100 dry grains in function of the goat manure doses, for seeding densities of 75,000 plants ha ${ }^{-1}$ (a) and 35,500 plants ha ${ }^{-1}(b)$ of cowpe bean 
The results for grain weight are within the range described by Freire Filho et al. (2012), from less than $10 \mathrm{~g}$ (extra-small grains) to more than $30 \mathrm{~g}$ (extra grains). However, most of the cultivars range from $15 \mathrm{~g}$ to $25 \mathrm{~g}$, concentrated mainly from 15 g to 20 g per 100 grains (Freire Filho et al., 2011). Freitas (2015) evaluating traditional varieties of cowpea found a mass of 100 dry grains of 20.6, 20.2, 20.8, 24.7 and 21.0 for the varieties Upanema, Umarizal, Itaú, Carnaúbais, and Baraunas, respectively, values lower than those found here, while Pereira (2014) reported higher values.

Grain size is one of the most important agronomic traits for pricing, since consumers choose heavier grains, determining the quality to commercialization (Bertini et al., 2010; Ehlers \& Hall, 1997).

For dry grains yield, there was an increase with the addition of different doses of goat manure, with a mean value of

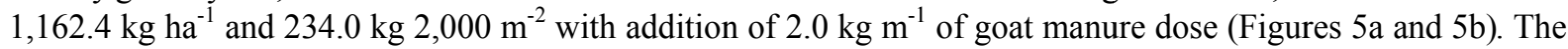
higher sowing density allowed $47 \%$ of the increase in productivity. Gain in productivity is essential for farmers in areas of severe climate, as the Northeast of Brazil.

The addition of organic matter may enhance the soil structure, reduces plasticity and cohesion, increasing the water retention and aeration, which allows the root growth and the increase in productivity (Leite; Gomes \& Santos, 2012). Torres et al. (2008) found lower productivity of Pingo de Ouro cowpea, $0.34 \mathrm{tha}^{-1}$ or a $340 \mathrm{~kg} \mathrm{ha}^{-1}$.
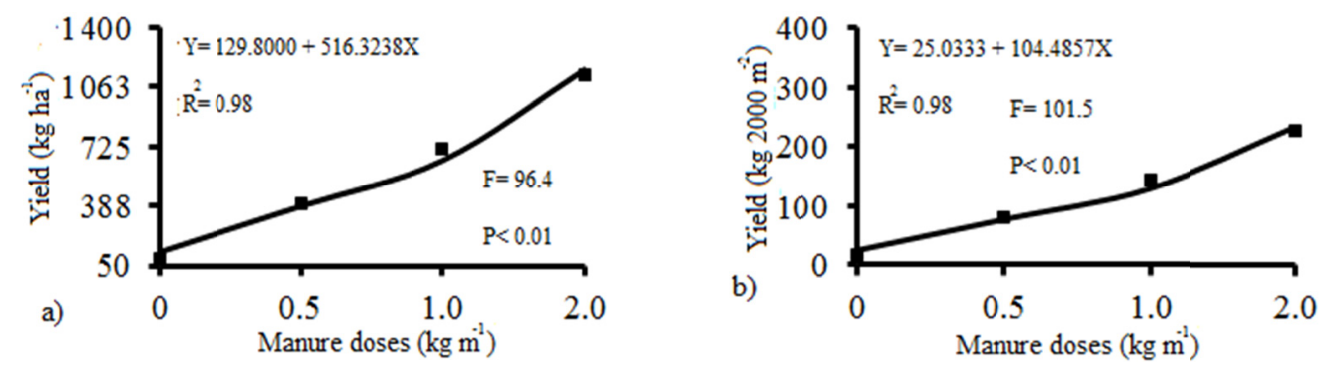

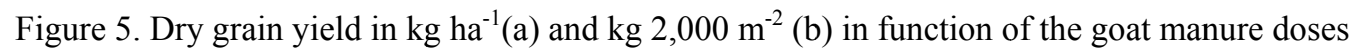

Santos and Lima (2015) reported 883.1; 984.0 and $948.4 \mathrm{~kg} \mathrm{ha}^{-1}$ for the Sempre Verde, Garanjão and Roxinho types at the municipality of Coremas, PB, Brazil, in rainfed cultivation. Freitas (2015) found mean productivity of $1,056.9 \mathrm{~kg} \mathrm{ha}^{-1}$ evaluating the genetic potential of traditional varieties of cowpea for the production of dry and green grains, value lower than we found.

The yield depends on the fertilizer used. Pereira et al. (2013) reported higher yield using earthworm fertilizer $\left(1,831 \mathrm{~kg} \mathrm{ha}^{-1}\right)$ than bovine and goat manures $\left(1,563\right.$ and 1,529 $\mathrm{kg} \mathrm{ha}^{-1}$, respectively). Pereira also found higher values concerning our results, what was assigned to the use of a higher dose of fertilization ( $4.0 \mathrm{~kg}$ per seed hole) than used here (maximum of $2.0 \mathrm{~kg} \mathrm{~m}^{-1}$ ). According to Abreu, Cansi \& Juriatti (2007), the use of creole varieties constitutes a low-cost alternative for small farmers, who holds knowledge of the local varieties production.

\section{Conclusions}

We observed mean values of 25.07 and $26.3 \mathrm{~g}$ (100 dry grains) for 75,000 and 37,500 plants ha ${ }^{-1}$, respectively, at the dose of $2.0 \mathrm{~kg} \mathrm{~m}^{-1}$ of manure.

The fertilization with $2.0 \mathrm{~kg} \mathrm{~m}^{-1}$ of goat manure leads to the largest dry grain yield, $1,162.4 \mathrm{~kg} \mathrm{ha}^{-1}(234 \mathrm{~kg} 2,000$ $\mathrm{m}^{-2}$ ). Comparing only seeding densities the highest values were observed in the density of 75,000 plants ha ${ }^{-1}$ with

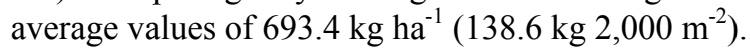

We recommend the use of goat manure associated with higher sowing density as a viable alternative for cowpea crops.

\section{Acknowledgements}

Special thank the Jitirana (Merremia aegyptia L.) Research Group committed to the study of spontaneous species of the Caatinga Biome as fertilizer source and the Department of Agronomic and Forestry Sciences the Federal Rural Semi-Arid University (UFERSA), for the support in the conduction of the project.

\section{References}

Bertini, C. H. C. M., Almeida, W. S. A., Silva, A. P. M. S., Silva, J. W. L., \& Teófilo, E. M. (2010). Análise multivariada e índice de seleção na identificação de genótipos superiores de feijão-caupi. Acta Scientiarum. 
Agronomy, 32(4), 613-619. https://doi.org/10.4025/actasciagron.v32i4.4631

Calvalcante, E. S., Góes, A. C. P., Mélem Junior, N. J., Rocha, N. J., M. M., \& Freire Filho, F. R. (2013). Avaliação de linhagens de feijão-caupi no Amapá. III Congresso Nacional de Feijão-Caupi. Anais... Recife. Retrieved from https:// www.bdpa.cnptia.embrapa.br/consulta/busca?b=ad\&id

Cardoso, M. J., \& Ribeiro, V. Q. (2006). Desempenho agronômico do feijão caupi, cv. Rouxinol, em função de espaçamento entre linhas e densidade de plantas sob regime de sequeiro. Revista Ciência Agronômica, 37(2), 102-105.

Carmo-Filho, F., Sobrinho, J. E., \& Maia Neto J. M. (1991). Dados climatológicos de Mossoró: Um município semi-árido nordestino (p. 121). Mossoró, RN: UFERSA.

Carpentieri-Pípolo, V., Souza, A., Silva, D. A., Barreto, T. P., Garbuglio, D. D., \& Ferreira, J. M. (2010). Avaliação de cultivares de milho crioulo em sistema de baixo nível tecnológico. Acta Scientiarum. Agronomy, 32(2), 229-233.

Ehlers, J. D., \& Hall, A. E. (1997). Cowpea (Vigna unguiculata L. Walp). Amsterdam: Field Crops Research, 53(3), 187-204. https://doi.org/10.1016/S0378-4290(97)00031-2

Embrapa (Empresa Brasileira De Pesquisa Agropecuária). (2006). Sistema brasileiro de classificação de solos (2nd ed., p. 306). Rio de Janeiro: Embrapa.

Figueiredo, C. C., Ramos, M. L. G., Mcmanus, C. M., \& Menezes, A. M. (2012). Mineralização de esterco de ovinos e sus influência na produção de alface. Horticultura Brasileira, 30(1), 175-179. https://doi.org/ 10.1590/S0102-05362012000100029

Freire Filho, F. R., Ribeiro, V. Q., Rocha, M. M., Silva, K. J. D., Nogueira, M. S. R., Rodrigues, E. V., ... Rodrigues, E. V. (2012). Production, Breeding and the Potential of cowpea crop in Brazil (p. 49). Embrapa, Brazil. Retrieved from https://www.embrapa.br/.../production-breeding-and-potential-of-cowpea-cropin-bra

Freire Filho, F. R., Ribeiro, V. Q., Rocha, M. M., Silva, K. J. D., Nogueira, M. S. R., \& Rodrigues, E. V. (2011). Feijão-caupi no Brasil: Produção, Melhoramento Genético, Avanços e Desafios (p. 81). Embrapa Meio-Norte. Retrieved from https://www.alice.cnptia.embrapa.br/bitstream/doc/916831/1/feijaocau pi.pdf

Freitas, G. G. F. (2015). Potencial genético de variedades tradicionais de feijão caupi para a produção para a produção de grãos secos e verdes (60f, Dissertação (Mestrado), Universidade Federal Rural do Semi-Árido, Mossoró).

IBGE (Instituto Brasileiro de Geografia e Estatística). (2017). Estatística da Produção Agrícola. Retrieved from https://ww2.ibge.gov.br/home/estatistica/indicadores/agropecu aria/lspa/lspa_201709_6.shtm

Jandel Scientific. (1991). Table Curve: Curve Fitting Software (p. 280). Jandel Scientific. Retrieved from https://www.scielo.br/scielo.php?script=sci_nlinks\&ref=000090\&pid=S1806...lng...

Kronka, S. N., \& Banzato, D. A. (1995). Estat: Sistema para análise estatística (V. 2, 3rd ed., p. 234). Jaboticabal: FUNEP.

Leite, M. J. H., Gomes, A. D. V., \& Santos, R. V. (2012). Cultivo do sorgo forrageiro Sorghum bicolor (L.) Moench (S. vulgare Pers.) no semiárido. Revista Verde, 7(4), 06-09.

Lima, L. K. S. (2014). Desenvolvimento do feijão caupi em função da utilização de resíduo da indústria do café como fonte de potássio (80 f., Dissertação (Mestrado em Agronomia/Fitotecnia), Centro de Ciências Agrárias, Universidade Federal do Ceará, Fortaleza). Retrieved from https://www.repositorio.ufc.br/ bitstream/riufc/14905/1/2014_dis_lkslima.pdf

Matos Filho, C. H. A., Gomes, R. L. F., Rocha, M. M., Freire Filho, F. R., \& Lopes, A. C. A. (2009). Potencial produtivo de progênies de feijão-caupi com arquitetura ereta de planta. Ciência Rural, 39(2), 348-354. https://doi.org/10.1590/S0103-84782009000200006

Oliveira, F. J. V., Carvalho, R. N., Soares, T. F., Figueiredo Neto, A., Anjos, J. B., \& Souza, A. V. V. (2011). Avaliação de diferentes dosagens de esterco caprino na cultura do milho pipoca (Zea mays L.) na região do semiárido do vale do são francisco. Revista Barriguda, 6(2), 323-331.

Pereira, M. F. S. (2014). Otimização do consórcio rabanete e caupi-hortaliça adubado com espécie espontânea (85 f., Tese (Doutorado em Fitotecnia), Universidade Federal Rural do Semi-Árido, Mossoró). Retrieved from https://ppgfito.ufersa.edu.br/dissertacoes-de-mestrado 
Pereira, R. F., Cavalcante, S. N., Lima, A. S., Maia Filho, F. C. F., \& Santos, J. G. R. (2013). Crescimento e rendimento de feijão Vigna submetido à adubação orgânica. Revista Verde, 8(3), 91-96.

Pereira, T. A., Souto, L. S., Sá, F. V. S., Paiva, E. P., Souza, D. L., Silva, V. N., \& Souza, F. M. (2014). Esterco ovino como fonte orgânica alternative para o cultivo do girrassol no semiárido. Agropecuária Cientifica no Semiárido, 10(1), 59-64.

Rêgo, L. G. S., Martins, C. M., Silva, E. F., Silva, J. J. A., \& Lima, R. N. S. (2016). Pedogênese e classificação de solos de uma fazenda experimental em Mossoró, Rio Grande do Norte, Brasil. Revista Caatinga, 29(4), 1036-1042. https://doi.org/10.1590/1983-21252016v29n430rc

Santos, D. P., \& Lima, L. K. S. (2015). Avaliação agronômica de variedades de feijão-caupi em cultivo de sequeiro no município de Coremas-PB. Revista Verde de Agroecologia e Desenvolvimento Sustentável, 10(1), 218-222. https://doi.org/10.18378/rvads.v10i1.2950

Santos, J. F., Grangeiro, J. I. T., Brito, C. H., \& Santos, M. C. C. A. (2009). Produção e componentes produtivos de variedades de feijão-caupi na microrregião cariri Paraibano. Engenharia Ambiental, 6(1), 214-222.

Sousa, R. R. de., Oliveira, D. G., Rocha, M. M., Silva, K. J. D., Sousa, J. L. M., \& Costa, M. M. (2013). Variabilidade genética e potencial agronômico de genótipos de feijão caupi de porte semieretolereto no municipio de Teresina-PI (p. 5). III Congresso Nacional de Feijão-Caupi. Anais... Recife, Brazil. Retrieved from http://www.embrapa.br/.../variabilidade-genetica-e-potencial-agronomico-de-genotip...

Torres Filho, J., Costa, F. M. C. D., Nunes, M. C. C., Silveira, L. M., Antônio, R. P., Barros Junior, A. P., \& Borges, J. Q. C. (2013). Avaliação de genótipos de feijão caupi ereto e semi-ereto em diferentes épocas no município de Mossoró-RN (p. 5). III Congresso Nacional de Feijãocaupi. Anais... Recife, Brazil. Retrieved from https://www.bdpa.cnptia.embrapa.br/../busca?...\%22CONGRESSO $\% 20$ NACIONAL\%...

Torres, S. B., Oliveira, F. N., Oliveira, R. C., \& Fernandes, J. B. (2008). Produtividade e morfologia de acessos de caupi, em Mossoró, RN. Horticultura Brasileira, 26(4), 537-539. https://doi.org/10.1590/S0102-053620 08000400023

Wander, A. E. (2007). Produção e consumo de feijão no Brasil, 1975-2005. Informações Econômicas, 37(2), 7-21.

\section{Copyrights}

Copyright for this article is retained by the author(s), with first publication rights granted to the journal.

This is an open-access article distributed under the terms and conditions of the Creative Commons Attribution license (http://creativecommons.org/licenses/by/4.0/). 